\title{
Seroprevalence of Neospora caninum in local Bali dog
}

\author{
I Made Dwinata ${ }^{1}$, Ida Bagus Made Oka ${ }^{1}$, Kadek Karang Agustina ${ }^{2}$ and I Made Damriyasa ${ }^{3}$
}

1. Department of Parasitology, Faculty of Veterinary Medicine, Udayana University, PB. Sudirman St. Campus, Denpasar, Bali 80223, Indonesia; 2. Department of Public Health, Faculty of Veterinary Medicine, Udayana University, PB. Sudirman St. Campus, Denpasar, Bali 80223, Indonesia; 3. Department of Clinical Pathology and Diagnosis, Faculty of Veterinary Medicine, Udayana University, PB. Sudirman St. Campus, Denpasar, Bali 80223, Indonesia.

Corresponding author: I Made Dwinata, e-mail: made_dwinata@unud.ac.id

Co-authors: IBMO: okaibm@yahoo.co.id, KKA: k.agustina@unud.ac.id, IMD: madedamriyasa@yahoo.com Received: 28-12-2017, Accepted: 01-06-2018, Published online: 14-07-2018

doi: 10.14202/vetworld.2018.926-929 How to cite this article: Dwinata IM, Oka IBM, Agustina KK, Damriyasa IM (2018) Seroprevalence of Neospora caninum in local Bali dog, Veterinary World, 11(7): 926-929.

\begin{abstract}
Aim: The aim of this research was to identify the seroprevalence of Neospora caninum in local Bali dogs.

Materials and Methods: A total of 147 local Bali dog serum samples have been examined for antibodies of $N$. caninum using enzyme-linked immunosorbent assay test.

Results: The results confirmed that 5 (3.4\%) local Bali dogs have antibody for $N$. caninum. There were no significant differences in seroprevalence of Neospora infection in local Bali dogs between different genders, ages, and take care methods $(\mathrm{p}>0.05)$.
\end{abstract}

Conclusion: The results provided evidence for the presence of $N$. caninum infection in local Bali dogs and thus the risk to Bali cattle and dog health.

Keywords: local Bali dog, Neospora caninum, seroprevalence.

\section{Introduction}

Neospora caninum is an apicomplexan protozoon that can infect dogs, cattle, and other mammalians $[1,2]$. Dogs are well known as a definitive host and can spread oocyst $[3,4]$. Dogs get infection by oral transmissions and transplacental $[5,6]$. Severe Neosporosis usually occurs in congenital cases. It causes neuromuscular symptoms with paralysis of the legs and leads to the lethal encephalomyelitis $[7,8]$. $N$. caninum has been regarded as the major cause of abortion with great economic impact in cattle industry [9-12]. Prevention and control of Neosporosis in cattle are necessary, especially, if there is a role of wildlife in its transmission [13-16]. The seroprevalence of $N$. caninum has been reported to infect dogs in many countries, such as $20.9 \%$ of prevalence in farm and kennel dogs in Southern Italy [17], $31 \%$ in stray dogs in Iran [18], 55.5\% of prevalence in Turkey [19], and 15\% of prevalence in China [20], but there are no data reported in Indonesia.

Serological results in multiple species, including domestic, wildlife, and zoo animals, provide evidence that many species have been exposed to this parasite [12]. Nowadays, data about Neospora infection in animals in Asia, particularly, in Indonesia are limited. There was a study reported that Neosporosis in

Copyright: Dwinata, et al. Open Access. This article is distributed under the terms of the Creative Commons Attribution 4.0 International License (http://creativecommons.org/licenses/ by/4.0/), which permits unrestricted use, distribution, and reproduction in any medium, provided you give appropriate credit to the original author(s) and the source, provide a link to the Creative Commons license, and indicate if changes were made. The Creative Commons Public Domain Dedication waiver (http:// creativecommons.org/publicdomain/zero/1.0/) applies to the data made available in this article, unless otherwise stated.
Bali cattle was $5.5 \%$ in Bali. It is believed to cause the reproductive disorder that occurs in Bali cattle in Bali [21]. While the seroprevalence of Neosporosis in cattle has been reported $44.9 \%$ in Taiwan [22] and $9 \%$ in Malaysia on dairy farms [23]. Recent studies reported a high seroprevalence of cattle Neosporosis, i.e., $43 \%$ in Pakistan [24], 37.7\% in Turkey [19], and $46.9 \%$ in Northern Provinces of Thailand [25].

In Bali, the pattern of cattle productions is generally traditional [26,27]; this situation allows free roaming dogs to access the cowshed, interact, and spreading agents. Therefore, it is necessary to study the epidemiology of Neosporosis in local Bali dogs in Bali to reveal the role of dogs as a source of transmission of Neosporosis in Bali cattle.

\section{Materials and Methods \\ Ethical approval}

This study was approved by the ethics commission for the use of animal in the research and education of The Faculty of Veterinary Medicine Udayana University and declared eligible with reference No. 275a/KE-PH/XII/2016.

\section{Samples}

The sample size was calculated using the formula proposed by Thrusfield [28]. A total of 147 local Bali dog serum samples have collected from Bali, Indonesia. Each sample is grouped by gender, age, and take care methods, i.e., 108 males and 39 females, $87<1$ year old and 80 more than 1 year old, and 77 caged and 70 free roam, respectively. Dog samples were targeted in local Bali dogs that live around the Bali cattle farm. 


\section{Preparation of the serum samples}

Blood sampling was performed in eight regencies located in the study area. After the dogs had fasted overnight, $5 \mathrm{ml}$ of blood was taken from the cephalic vein and collected into vacuum tubes without an anticoagulant agent. Sera were obtained by centrifugation for $10 \mathrm{~min}$ at $358 \mathrm{~g}$ and stored at $-20^{\circ} \mathrm{C}$ until assayed [29] at the Department of Parasitology, Faculty of Veterinary Medicine, Udayana University.

\section{Enzyme-linked immunosorbent assay (ELISA)}

The presence of antibodies to $N$. caninum was detected by indirect ELISA using a commercially available antigen of $N$. caninum (ID.Vet ${ }^{\circledR}$, ID Screen $N$. caninum Indirect Multi-species). The kit procedure is based on a solid-phase indirect ELISA. A positive result is indicated by the development of a blue color. The reaction is stopped by adding of the stop solution; the color changes to yellow. The result is read by a microplate photometer, where the optical density is measured at $450 \mathrm{~nm}$ [30].

\section{Statistical analysis}

Seroprevalence was statistically analyzed, considering the variables of gender, age, and take care methods. The data analysis was performed with Pearson Chi-square test using SPSS 17.0, which the differences were considered statistically significant when $\mathrm{p} \leq 0.05$.

\section{Results and Discussion}

This is the first report about $N$. caninum seroprevalence in dogs in Indonesia. We found that the seroprevalence of $N$. caninum in local Bali dogs was $3.4 \%(5 / 147)$. This data is supporting the previous report that found seroprevalence of $N$. caninum in Bali cattle in the area of study [21], indicates that there is a relationship between Neosporosis in dogs and Bali cattle in Bali.

This result is in agreement to previous studies that found $6.4 \%$ of seroprevalence of $N$. caninum in dogs using indirect fluorescent antibody test in Italy [31], 8.3\% in Amazon, Brazil [32], and $6.25 \%$ in Jilin, China using Neospora agglutination test [33].

This finding is lower than the seroprevalence of dog's Neosporosis in some previous studies, i.e., $15 \%$ in Central China [20], 16.36\% in Poland [34], and $31 \%$ in Iran [18]. The differences in seroprevalence of $N$. caninum in dogs in some countries indicate that there are the factors that affected the result such as type of dog, geo and topography, population, management system, and examination methods used [35-37]. Low prevalence of $N$. caninum in local Bali dogs is probably due to environmental factors that are less suitable for oocyst development. Transmission is mostly from dog to dog by eating sporulated oocyst [1], and rarely found dogs eat aborted cattle placenta in Bali. Season factor greatly influences the occurrence of Neosporosis [38], where this research was carried
Table-1: Seroprevalence of $N$. caninum in Bali local dogs in Bali.

\begin{tabular}{lccccc}
\hline Variable & Sample & Infected & $(\%)$ & $\chi^{2}$ & p value \\
\hline Gender & 108 & 3 & 2.8 & 0.488 & $0.609^{\text {ns }}$ \\
$\quad$ Male & 39 & 2 & 5.1 & & \\
$\quad \begin{array}{l}\text { Female } \\
\text { Age }\end{array}$ & & & & & \\
$\quad \leq 1$ year old & 87 & 2 & 2.3 & 0.789 & $0.399^{\text {ns }}$ \\
$\quad \begin{array}{l}\text { 1 years old } \\
\text { Upkeep method }\end{array}$ & 60 & 3 & 5.0 & & \\
$\quad$ Caged & 77 & 1 & 1.3 & 2.176 & $0.192^{\text {ns }}$ \\
$\quad$ Free roam & 70 & 4 & 5.7 & & \\
Total & 147 & 5 & 3.4 & & \\
\hline
\end{tabular}

${ }^{*}$ ns $=$ Not significant, $N$. caninum $=$ Neospora caninum

out in the dry season with hot temperatures that can disrupt the development of oocysts into an infective stage. In addition, the low number of oocysts released by natural $N$. caninum-infected dogs [4].

The presence of free-roaming dogs in Bali was so many [39]. With the detection of $N$. caninum antibodies in local Bali dogs will be a considerable threat to Bali cattle. The infection happens considering the cattle rearing system in Bali are still with semi-intensive and traditional [26,27]. Dog and Bali cattle have a close interaction that dogs can easily access the cattle house.

Based on the variables observed in this study (Table-1), all factors, i.e., gender, age, and upkeep methods were not significantly affected the seroprevalence of $N$. caninum in local Bali dogs $(\mathrm{p}>0.05)$. Regarding the dog gender, we found that $2.8 \%(3 / 108)$ positive male dogs and $5.1 \%(2 / 39)$ positive female dogs. This data is in agreement with the previous report [20,40]. However, a study in 2011 found a higher prevalence in female dogs than male dogs [37]. Related to the ages of dogs, the result shows that the seroprevalence of under 1 years old dogs was $2.3 \%$ while $5 \%$ in dogs of upper 1 year of age. This finding is similar to the report in Italy [31] and Pakistan [24], and there was no age effect on the magnitude of $N$. caninum seroprevalence. However, in contrary to the statement that $N$. caninum infections have a correlation to the age of dogs, young dogs were more vulnerable than adult dogs [41]. According to the upkeep methods, the seroprevalence of $N$. caninum on caged and free-roaming dogs was, respectively, $1.3 \%$ and $5.7 \%$. The similar result reported in Brazil [42] but slightly different in Italy, the seroprevalence of Neosporosis in stray dogs was $35.8 \%$ higher than caged dogs which was $17.3 \%$ [17]. This is explained that free-roaming dogs are more likely to contact with the source of infection either from the infective $N$. caninum oocyst or the aborted cattle placenta.

\section{Conclusion}

The seroprevalence of $N$. caninum in local Bali dogs was $3.4 \%$. Gender, ages, and take care methods were not affected the prevalence of this parasite. 


\section{Authors' Contributions}

IMD participated in the fieldwork, sample collection, laboratory work, ELISA test, and manuscript drafting; IBMO participated in the fieldwork, sample collection, laboratory work, and manuscript drafting; KKA participated in the fieldwork and participated in manuscript drafting; IMD designed the research and participated in manuscript drafting. All authors read and approved the final manuscript.

\section{Acknowledgments}

The authors would like to thank Udayana University for providing fund and support for this research through Research Contract Number: 246-311/ UN14.2/PNL.01.03.00/2015.

\section{Competing Interests}

The authors declare that they have no competing interests.

\section{References}

1. Dubey, J.P., Schares, G. and Ortega-Mora, L.M. (2007) Epidemiology and control of neosporosis and Neospora caninum. Clin. Microbiol. Rev., 20(2): 323-367.

2. Dubey, J.P. and Schares, G. (2011) Neosporosis in animalsthe last five years. Vet. Parasitol., 180: 90-108.

3. McAllister, M.M., Dubey, J.P., Lindsay, D.S., Jolley, W.R., Wills, R.A. and McGuire, A.M. (1998) Dogs are definitive host of N. caninum. Int. J. Parasitol., 28: 1473-1478.

4. Schares, J.R., Panchev, N., Barutzki, D., Heydorn, A.O., Bauer, C. and Conraths, F.J. (2005) Oocysts of Neospora caninum, Hammondia heydoni, Toxoplasma gondii and Hammondia hammondi in faeces collected from dogs in Germany. Int. J. Parasitol., 35: 1525-1537.

5. Dijkstra, T., Eysker, M., Schares, G., Conraths, F.J., Wouda, W. and Barkema, H.W. (2001) Dogs shed Neospora caninum oocysts after ingestion of naturally infected bovine placenta but not after ingestion of colostrum spiked with Neospora caninum tachyzoites. Int. J. Parasitol., 31: 747-752.

6. Bartels, C.J., Huinink, I., Beiboer, M.L., vanSchaik, G., Wouda, W. and Dijkstra, T. (2007) Quantification of vertical and horizontal transmission of Neospora caninum infection in Dutch dairy herds. Vet. Parasitol., 148: 83-92.

7. Bjerkas, I., Mohn, S.F. and Prestus, J. (1984) Unidentified cyst-forming sporozoon causing encephalomyelitis and myositis in dog. Z. Parasitenkd., 70: 271-274.

8. Dubey, J.P., Carpenter, J.L., Speer, C.A., Topper, M.J. and Uggla, A. (1988) Newly recognized fatal protozoan disease of dogs. J. Am. Vet. Med. Assoc., 192: 1269-1285.

9. Dubey, J.P. (2003) Review of Neospora caninum and neosporosis in animals. Korean J. Parasitol., 41: 1-16.

10. Anderson, M.L., Andrianarivo, A.G. and Conrad, P.A. (2000) Neosporosis in cattle. Anim. Reprod. Sci., 60-61: 417-431.

11. McAllister, M.M. (1999) Uncovering the biology and epidemiology of N. caninum. Parasitol. Today, 5: 216-217.

12. Almeria, S. (2013) Neospora caninum and wildlife, Review article. ISRN Parasitol., 2013: 1-23.

13. Damriyasa, I.M., Bauer, C., Edelhofer, R., Failing, K., Lind, P., Petersen, E., Schares, G., Tenter, A.M., Volmer, R. and Zahner, H. (2004) Cross-sectional study in pig breeding farm in Hesse, Germany: prevalence of antibodies to Toxoplasma gondii, Sarcocystis spp. and N. caninum in sows and analyses of risk factors. Vet. Parasitol., 126: 271-286.

14. Andre, M.R., Adania, C.H., Teixeira, R.H., Silva, K.F., Jusi, M.M. and Machado, S.T. (2010) Antibodies to Toxoplasma gondii and Neospora caninum in captive neotropical and exotic wild canids and felids. J. Parasitol., 96: 1007-1009.

15. Bartley, P.M., Wright, S.E., Zimmer, I.A., Roy, S., Kitchener, A.C. and Meredith, A. (2013) Detection of Neospora caninum in wild Carnivorans in Great Britain. Vet. Parasitol., 192: 279-283.

16. Bevins, S., Blizzard, E., Bazan, L. and Whitley, P. (2013) Neospora caninum exposure in overlapping populations of coyotes (Canis latrans) and feral swine (Sus scrofa). $J$. Wildl. Dis., 49: 1028-1032.

17. Paradies, P., Capelli, G., Testini, G., Cancessi, C., Alexander, J.T. and Otranto, D. (2007) Risk factor for canine neosporosis in farm and kennel dogs in southern Italy. Vet. Parasitol., 145: 240-244.

18. Yagoob, G. (2011) Seroprevalence of Neospora caninum in stray dogs. Am. J. Anim. Vet. Sci., 6(3): 100-104.

19. Ocal, N., Atmaca, H.T., Albay, M.K., Deniz, A., Kalender, H., Yildiz, K. and Kul, O. (2014) A new approach to Neospora caninum infection epidemiology: Neosporosis in integrated and rural dairy farms in Turkey. Turkish J. Vet. Anim. Sci., 38: 161-168.

20. Wang, S., Yao, Z., Zhang, N., Wang, D., Ma, J., Liu, S., Zheng, B., Zhang, B., Liu, K. and Zhang, H. (2016) Serological study of Neospora caninum infection in dogs in central China. Parasite, 23(25): 1-5.

21. Damriyasa, I.M., Schares, G. and Bauer, C. (2010) Seroprevalence of antibodies to Neospora caninum in Bos javanicus ("Bali cattle") from Indonesia. Trop. Anim. Health Prod., 42(1): 95-98.

22. Oei, H.K., Huang, C.C., Yang, C.H. and Lee, S.H. (2000) Serological survey and first finding of $N$. caninum in Taiwan, and the detection of ist antibodies in various body fluid of cattle. Vet. Parasitol., 90: 47-55.

23. Soon, C.T. (2004) Seroepidemiology, Diagnosis, Isolation and Characterisation of Neospora caninum Among Cattle in Malaysia. Thesis Dissertation, Putra Malaysia University.

24. Nazir, M.M., Maqbool, A., Khan, M.S., Sajjid, A. and Lindsay, D.S. (2013) Effects of age and breed on the prevalence of Neospora caninum in commercial dairy cattle from Pakistan. J. Parasitol., 99(2): 368-370.

25. Inpankaew, T., Jittapalapong, S., Mitchell, T.J., Sununta, C., Igarashi, I. and Xuan, X. (2014) Seroprevalence of Neospora caninum infection in dairy cows in Northern provinces, Thailand. Acta Parasitol., 9(2): 305-309.

26. Agustina, K.K., Dharmayudha, A.A.G.O. and Wirata, I.W. (2013) Prevalence of Toxocara vitulorum in cows and calves of Bali cattle in Eastern Bali. Bul. Vet. Udayana, 5(1): 1-6.

27. Suwiti, N.K., Besung, I.N.K, Sriyani, N.L.P., Sampurna, P. and Agustina, K.K. (2016) Aplikasi teknologi pada peternakan sapi bali dengan sistem pemeliharaan berbasis terintegrasi lingkungan. J. Udayana Mengabdi., 15(2): 216-222.

28. Thrusfield, M. (2007) Veterinary Epidemiology. $3^{\text {rd }}$ ed. Wiley-Blackwell, London. p624.

29. Machacova, T., Eva Bartova, E., Sedlak, K., Slezakova, R., Budikova, M., Piantedosi, D. and Veneziano, V. (2016). Seroprevalence and risk factors of infections with Neospora caninum and Toxoplasma gondii in hunting dogs from Campania region, southern Italy. Folia Parasitol., 63(12): $1-5$.

30. Cedeno, D.Q. and Benavides, B. (2013). Seroprevalence and risk factors associated to Neospora caninum in dairy cattle herds in the municipality of Pasto, Colombia. Rev. MVZ Córdoba, 18(1): 3311-3316.

31. Ferroglio, E., Pasino, M., Ronco, F., Bena, A. and Trisciuoglio, A. (2007) Seroprevalence of antibodies to Neospora caninum in urban and rural dogs in north-west Italy. Zoonoses Pub. Health, 54: 135-139.

32. Canon-Franco, W.A., Bergamaschi, D.P., Labruna, M.B., Camargo, L.M.A., Souza, S.L.P., Silva, J.C.R., Pinter, A., Dubey, J.P. and Gennari, S.M. (2003) Prevalence of antibodies to Neospora caninum in dog from Amazon, Brazil. Vet. Parasitol., 115: 71-74. 
33. Yang, Y., Zhang, Q., Kong, Y., Ying, Y., Chun, O., Kwok, H., Liang, H. and Dubey, J.P. (2014) Low prevalence of Neospora caninum and Toxoplasma gondii antibodies in dogs in Jilin, Henan and Anhui provinces of the Peoples's Republic of China. BMC Vet. Res., 10(295): 1-6.

34. Katarzyna, P. and Michal, M. (2008) Seroprevalence of Neospora caninum in dogs in South-Western Poland. Vet. Parasitol., 153: 168-171.

35. Barber, J.S., Gasser, R.B., Ellis, J., Reichel, M.P., McMillan, D. and Trees, A.J. (1997) Prevalence of antibodies to Neospora caninum in different Canid populations. $J$. Parasitol., 83: 1056-1058.

36. Basso, W., Venturini, L., Venturini, M.C., Moore, P., Rambeau, M. and Unzaga, J.M. (2001) Prevalence of Neospora caninum infection in dogs from beef-cattle farms, dairy farms, and from urban areas of Argentina. $J$. Parasitol., 87: 906-907.

37. Gozdzik, K., Wrzesien, R., Wielgosz-Ostolska, A., Bien, J., Kozak-Ljunggren, M. and Cabaj, W. (2011) Prevalence of antibodies against Neospora caninum in dogs from urban areas in Central Poland. Parasitol. Res., 108: 991-996.

38. Donahoe, S.L., Lindsay, S.A., Krockenberger, M.,
Phalen, D. and Slapeta, J. (2015) A review of neosporosis and pathologic findings of Neospora caninum infection in wildlife. Int. J. Parasitol. Parasites Wildl., 4: 216-238.

39. Morters, M.K., McKinley, T.J., Restif, O., Conlan, A.J.K., Cleaveland, S., Hampson, K., Whay, H.R., Damriyasa, I.M. and Wood, J.L.N. (2014) The demography of free-roaming dog populations and applications to disease and population control. J. Appl. Ecol., 51: 1096-1106.

40. Oliveira, J.M., deFatma, C.M., Oshiro, L.M. and Andreotti, R. (2014) Prevalence of Anti-Neospora caninum antibodies in dogs in the urban area of Campo Grande, Ms, Brazil. Braz. J. Vet. Parasitol., 13(4): 155-158.

41. Moura, A.B., Souza, A.P., Sartor, A.A., Bellato, V., Pisetta, G.M., Teixeira, E.B. and Junior, A.H. (2011) Neospora caninum antibodies and risk factors in dogs from Lages and Balneário Camboriú, SC. Arq. Bras. Med. Vet. Zootec., 63(1): 262-265.

42. Romanelli, P.R., Freire, R.L. and Vidotto, O. (2007) Prevalence of Neospora caninum and Toxoplasma gondii in sheep and dog from Guarapuava farm, Parana State, Brazil. Res. Vet. Sci., 82: 202-207. 